\title{
International Capital Flows' Effects and Banking Sector's Profitability in Emerging Countries: Exploring Turkey Case
}

\author{
Semliko Fulbert DOSSOU (iD a Ahmet AKSOY iD b \\ a Institute of Social Sciences, Gazi University, Faculty of Economics and Administrative Sciences, Department of Business \\ Administration, Ankara, Turkey. semliko.fd97@yahoo.com \\ b Institute of Social Sciences, Gazi University, Faculty of Economics and Administrative Sciences, Department of Business \\ Administration, Ankara, Turkey. a.aksoy@hbv.edu.tr
}

\begin{tabular}{|c|c|}
\hline ARTICLE INFO & ABSTRACT \\
\hline $\begin{array}{l}\text { Keywords: } \\
\text { International Capital Flows } \\
\text { Banking Sector Profitability } \\
\text { Emerging Countries } \\
\text { Generalized Moment } \\
\text { Method(GMM) }\end{array}$ & $\begin{array}{l}\text { Purpose - This paper investigated the effects of International Capital Flows (ICF) on Turkish } \\
\text { banking sectors profitability from } 1975 \text { to } 2016 \text {. The study is motivated (1) by the fact that ICFs can } \\
\text { be growth engines and/or a source of instability (according to their volatility, the way of used or } \\
\text { the environment); (2) by the scarcity of studies related to their effects on banking sector due to the } \\
\text { concentration of previous studies on economic growth. } \\
\text { Design/methodology/approach - ICFs are examined in this study with a close interest to their five } \\
\text { subcomponents and their effects on different types of Turkish banks. Two differents modèles } \\
\text { (linear and non-linear) were used with Panel GMM based on } 1974 \text { observations. Variables used } \\
\text { were: Return On Equity and Return On Asset of the banking sector as dependent variables; } \\
\text { Foreign Direct Investments, Foreign Portfolios Investments, External Debts Flows, External Aids } \\
\text { and Remittances as independent variables; GDP growth rate, inflation rate, interest rate, and trade } \\
\text { openness as control variables for robustness check. } \\
\text { Findings - The main findings were as follows: Foreign Direct Investments, External Aids and } \\
\text { Remittance had positive effects on banking profitability (ROE) in Turkey; while Foreign Portfolio } \\
\text { Investments and External long Term Debts had negative effects. In addition, only Foreign Direct } \\
\text { Investments had positive effects on banking profitability (ROA). Other capital flows'effects } \\
\text { remained insignificant. } \\
\text { Discussion - The negative effects of portfolios assumes that investors chose to invest more in stock } \\
\text { market and other capital markets than in banking sector for the considered period. The negative } \\
\text { effects of External Debts assumes that the acceptable threshold for debt was crossed. }\end{array}$ \\
\hline
\end{tabular}

\section{Introduction}

The banking sector (especially in emerging countries) is one of the strategic economic sectors that involves considerably high international capital flows. In order to maintain good economic growth in a program of continuous development, it is necessary to mobilize important national resources. And very often, this requires support from external capital. Thus international capital flows play an important role in financing a country's development needs. This is due to the fact that internal flows are limited and difficult to predict (Kinda., 2009). As is well known, financial integration permit capital circulation from capital-rich economies to capital-poor economies, for better returns ${ }^{1}$. By complementing limited domestic savings in capital-poor economies, these flows stimulate investment, promote the financial sector and accelerate economic growth in the host country by reducing capital costs.

The increasingly integrated character of the world today is no longer confined to trade alone; this integration also takes place in several other areas namely: technology, education, politics, and finance. Integration in its generality has many advantages but at the same time carries risks. This situation raises in the world of

\footnotetext{
1 According to IMF, Net capital inflows to developing countries rose from 30 billion US dollars in the 1980 s to about 50 billion dollars a year between 1987-89 then to more than 150 billion dollars between 1995-97. In the same vein, these flows rose to about US \$ 320 billion in 2000 -2005, before reaching a record level of US \$1.2 trillion in 2007.

Source: https://www.imf.org/external/pubs/ft/issues/issues17/fre/index.htm (accessed on 29 Jan. 2019)

In 2014, net inflows of private capital into emerging markets declined, mainly as a result of economic slowdown and geopolitical tensions

Source: http://www.un.org/en/development/desa/policy/wesp/wesp_archive/2015wesp-es-fr.pdf (accessed on 29 Jan. 2019)

Suggested Citation

Dossou, S. F., Aksoy, A. (2019). International Capital Flows' Effects and Banking Sector's Profitability in Emerging Countries:

Exploring Turkey Case, Journal of Business Research-Turk, 11 (4), 2456-2471.
} 
research especially in finance, reflections about the optimization of the said integration. That means, how to maximize the benefits of financial integration while minimizing its risks. A perplexing factor (in the benefitcost tradeoff improvement) in financial integration context, is the central often played by the banks in these flows intermediation (Committee, 2012). The experience of banking profitability in the past and the recent upsurge in international capital flows in many developing economies deserve the attention of researchers.

- International Capital Flows are subdivided into several subcomponents. It is necessary to distinguish the effects of each of these components.

- The effects of each of these components can be positive, null or even negative. In other words, International capital flows can be growth engines and/or a source of instability (according to their volatility, the way of used or the environment).

- Most of the previous studies only focused on one or two components of international capital flows (namely: foreign direct investments and foreign portfolio investments), analyzing their effects on economic growth. Our study tries to take into account five components and their effects on the banking sector's profitability in Turkey.

So the main objective of this study is to examine the effects of each component of international capital flows on different types of banks' profitability in Turkey as an emerging country over the 1975-2016 period. The remainder of this paper is organized as follows: Section 2 deals with the literature review. In Section 3 we present our methodology. Section 4 provides regression results and finally the conclusion.

\section{Literature Review}

The development and change, shown by the world economy since the 1980s, and expressed as globalization, brings the financial markets closer to each other with technological developments' contribution. Globalization, which shows its first effects on the financial markets, quickly spreads to other sectors and bring about significant changes in the resources and volume of international capital (Berksoy \& Saltoğlu, 1998).

\subsection{Conceptual Framework}

\section{Financial liberalization}

One important step in the process of globalization contributed significantly to the intensification of free movement of capital between countries (Yalçıner, 2012). The concept of liberalization can be understood under three headings: (1) commercial, (2) financial, (3) political and administrative; mainly, it is defined as "the removing of political and administrative controls mechanisms, and the internationalization of commercial and financial markets" (Dağdelen, 2004). According to another definition, financial and commercial liberalizations means "the reduction or abolition (partially or completely) of the existing controls in the economy on various markets such as foreign exchange markets, financial markets, labor markets, agricultural product markets " (A ğır, 2010).

After the demolition of Bretton Woods System in 1971, the level of competition on the globalizing world has rapidly increased and liberalization has emerged along with developing market structures. The liberalization process takes place in the form of commercial liberalization, financial liberalization and finally political and administrative liberalization. Trade liberalization aims to facilitate international free trade by removing controls of goods and services, while financial liberalization removes controls on financial instruments (internal financial liberalization). This aims to integrate domestic financial markets with international markets (external financial liberalization). Political and managerial liberalization includes policies aimed at extending the administration and management of the state to the interests of the domestic and foreign private sector and non-governmental organizations. For developing countries, financial liberalization means making the central bank more independent, freeing interest rates to reduce financial pressure, reducing (or eliminating) subsidized and directed loans (credits), and liberalizing external capital flows. These objectives are important in order to attract the international capital required for domestic investments (Ghosh, 2005). 


\section{Financial Globalization}

One of the factors underlying international capital movements is the concept of globalization. Among the various definitions of globalization in the literature, we retain that of Bakan and Şentürk (2012) according to which Globalization is expressed as "economic, political, social and cultural integration of the countries of the world, putting them into practice by forming common decisions and policies". Beyond this overview, the greatest impact of globalization on countries is seen in economic and financial spheres. The same authors define Financial globalization as "the integration of financial market and related activities, the free circulation of goods, services, capital, and information so that the world economy becomes a single market". The rapid change and development of technology are one of the most important factors that increase the dependence of countries on each other, which is a factor supporting globalization.

The economic globalization, which aims to make the world as a single market, integrate production, consumption, and competition, and eliminate the disparities in resource allocation has provided infrastructure for the birth of international trade. In addition, by removing the obstacles to financial globalization and capital movements, reducing of costs, increasing in domestic savings, and transferring technology from developed countries to developing countries, the development of financial sector could be achieved (Bakan \& Şentürk, 2012). One of the increasingly important features of globalization in recent years is capital market integration. Capital flows contribute to financial growth by encouraging investments (Masson, 2001).

\section{International Capital Flows and Their Different Components}

One of the largest volumes of international economic relations is the International capital movements. The international capital movement could be defined as "the transfer of funds from residents (persons or organizations) of a country to another country, which can be used for either consumption or investments" (Yalçıner, 2012).

According to the same author, the ways and investment instruments used by international capital movements are diverse and have a different specification from each other. From the point of view of fund ownership, they can be classified into two main groups. These are: (1) the official capital movements in the form of grants or credits to finance the economic development of countries and (2) the private capital movements in private qualities. On the other hand, they can also be compared according to indirect and direct function (mechanism) of funds or according to the types of investment's instruments used. Official capital movements can take place: (a) directly between governments, (b) between government agencies, (c) between international credit institutions and governments or government agencies. International capital movements in a private nature are a type of capital movement that showed a trend of development since the late 1980s. In our paper, taking "remittances" into account means that the use of the term "International Capital Flows" becomes more appropriate than the use of the term "Foreign Capital Flows". In fact, the concept of "International Capital Flows" is much wide and includes "Foreign Capital Flows". The following conceptual organogram (flowchart) will be followed to classify the different components of international capital flows. 


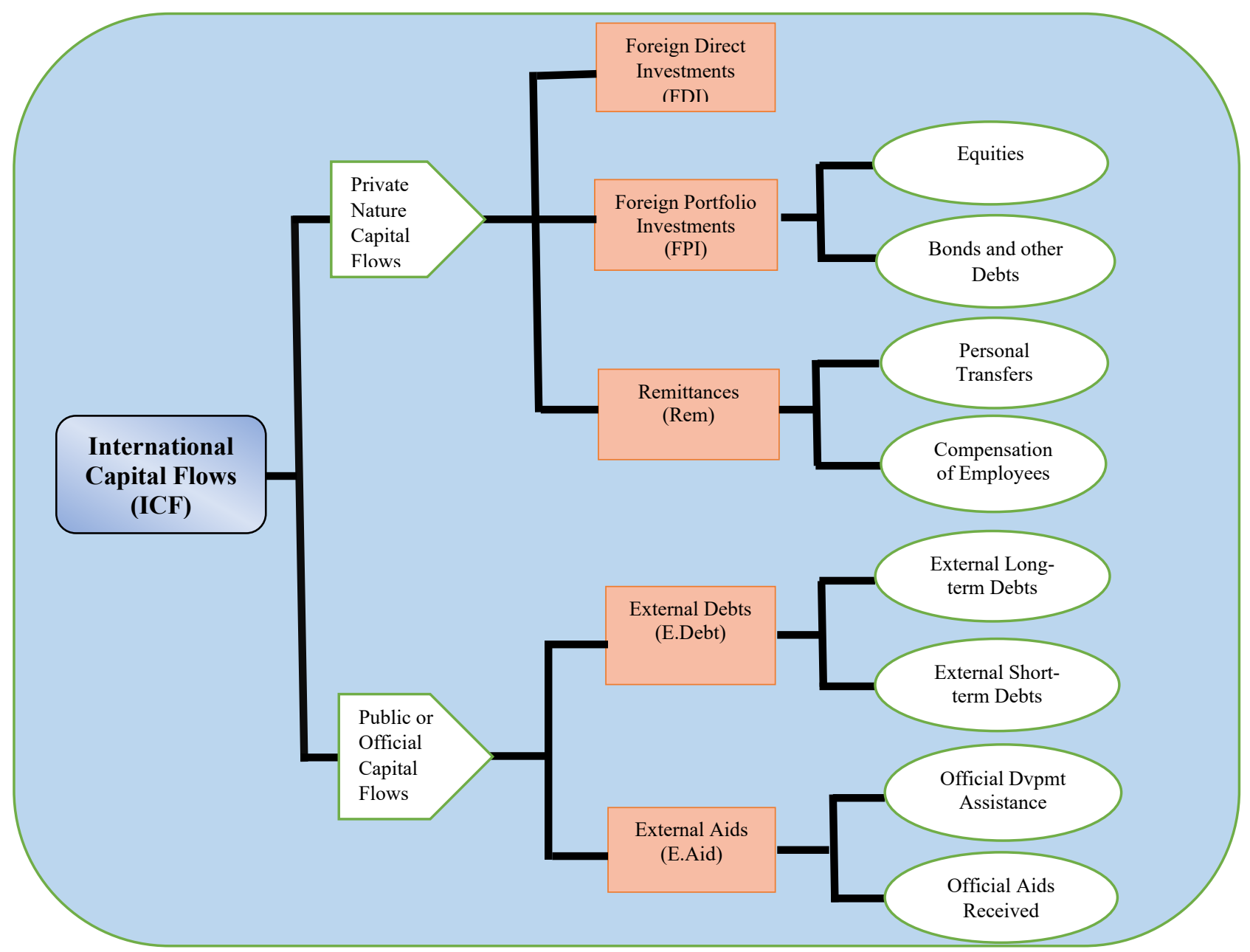

Figure 1: Conceptual Framework of International Capital Flows

Source: Created by the author based on the literature review

Foreign Direct Investments could represent "investments in fixed assets that entrepreneurs bring to the market outside their own countries to produce goods and services; it also refers to capital transfers to foreign countries by purchasing a company in a country, providing capital for a newly established company, or increasing the capital of an existing company. It is necessary that the capital invested in foreign direct investment be more than $10 \%$ of capital invested and that influence should be taken in the management of the company" (Yalçıner, 2012). In other words, foreign direct investment refers to "direct investment equity flows in the reporting economy. It is the sum of equity capital, reinvestment of earnings, and other capital. Direct investment is a category of cross-border investment associated with a resident in one economy having control or a significant degree of influence on the management of an enterprise that is resident in another economy. Ownership of 10 percent or more of the ordinary shares of voting stock is the criterion for determining the existence of a direct investment relationship" (World-Bank., 2018). For many countries, one of the major components or even the most important international capital flows is "foreign direct investment".

Portfolio equity includes "net inflows from equity securities other than those recorded as direct investment and including shares, stocks, depository receipts (national or global), and direct purchases of shares in local stock markets by foreign investors" (World-Bank., 2018). This is another form of cross-border investments in which foreign financial assets account represent less than $10 \%$ of the voting shares. This type of investment is made through passive investments of securities (like stocks), bonds and/or other similar financial means.

Between direct investments and portfolio investments, one of the most important differences refers to the influence level in the management and control of the investment done in the foreign country (Yalçıner, 2012). Accordingly, investments in which the investor has a direct control mechanism are referred to direct investments, and investments in which investor does not have direct control are called portfolio investments 
(Hymer, 1976). Another difference is related to volatility. Studies show that equity and portfolio investment bonds are highly volatile. That means that investors can easily liquidate their securities and decide to withdraw their investments in event of political instability, economic instability and/or government policies which are unfavorable to foreign investors.

External debts are "disbursements on long-term external debt and IMF purchases minus principal repayments on long-term external debt and IMF repurchases up to 1984. Beginning from 1985 this line includes the change in the stock of short-term debt (including interest arrears for long-term debt)" (World-Bank., 2018). According to the initial maturity period for repayment, external debt flows are classified into 2 categories: (1) Long-term debt flows, which is defined as "debt that has an original or extended maturity of more than one year and that is owed to foreigners by residents of a country and repayable in currency, goods, or services"; and (2) Short-term debt flows which is defined as "debt that has an original maturity of one year or less" (World-Bank., 2018).

External Aids: Generally perceived as official and public capital flows, they serve as a subsidy or official loan to stimulate growth, create wealth and promote the economic development of recipient countries. They are sometimes usable for purposes for which it would be impossible with private capital. For example, let's mention public consumption, donations and/or supports to face macro-disasters. The World Bank database (2018) classifies External Aids into two groups: the Official Development Assistance (ODA) and Official Aids Received (OAR).

Personal remittances include "personal transfers and compensation of employees". This form of private capital that migrates between individuals is a growing source of external financing. Data are composed of the sum of two items defined as bellow. (1) "Personal transfers consist of all current transfers in cash or in kind made or received by resident households to or from nonresident households. Personal transfers thus include all current transfers between resident and nonresident individuals. (2) Compensation of employees refers to the income of border, seasonal, and other short-term workers who are employed in an economy where they are not resident and of residents employed by nonresident entities" (WDI, 2018).

\subsection{Previous Empirical Studies}

The literature is filled (replete) with various studies dealing with the impacts of international capital flows on economic growth. However, to our knowledge, those focusing exclusively on the banking sector seem very scant. As it is well known, in each country the banking sector plays a crucial role in activities financing, contributing to economic growth. To this end, we consider that the results of previous workings related to the International Capital Flows (ICF) effects on economic growth could serve as inspiration and illumination in the present study. Synthesis of previous works is presented in this section.

\section{On Foreign Direct Investments'effects}

Blomstrom and al. (1996) conducted a study focusing on Over 100 countries for the period 1965-1985 and using Simple and multiple regressions. They found taht FDI had positive effect on economic growth. Borensztein and al. (1998) studying 69 developing countries over 1970-1989 found the same result using in panel data the technique of seemingly unrelated regressions (SUR) with IV cross-section. These findings were corroborated by Zhang (2001) and more recently by Adeola (2017). However, Carkovic and Levine (2002) found negative effects in their study about 72 countries over 1960-1995 with panel OLS technique and dynamic GMM estimation. Also, Hermes and Lensink (2003) focusing on 67 countries and using a panel estimation with cross-sectional OLS regression analysis over 1970-1995 found mixed effects. Their study showed a positive effect for host countries in which the financial system is sufficiently developed, and ambiguous or negative effects for SSA countries where the financial system is weak.

In addition, typically interested in banking sector Işık and Hassan (2002) used in their studies data envelopment analysis covering 1988-1996. As a result, they found that the cost-effectiveness of commercial banks and allocation efficiency are gradually declining during the period while the economy and technical efficiency increased. According to these authors, the liberalization process and the implementation of the New Economy Policy Program of the 1981-1990 period have helped increase entries of new banking. During the first years of transition to the new program, despite that the failure of banks' technical activities, it shows that a significant increase in technical efficiency was achieved after 1987. In addition, Işsk (2007) examines 
the effect of liberalization on bank efficiency and performance in the Turkish banking sector during 19811990 according to ownership (public, private or foreign). He found positive results.

Denizer and al. (2007) in their working from 1970 to 1994 used data envelopment analysis with production and mediation approaches. They found that the efficiency scores were falling; especially before liberalization, the banking systems of countries in their sample were following a more stationary course. K1lıç (2011) focusing his study on the Turkish banking sector between 2002 and 2009 compared the performance of banks with foreign shareholders before and after their partnership. The sector achieved positive performance in total, and from 2002 to 2009 technical activity was found to increase gradually. Fukuyama and Matousek (2011), using local and foreign banks operating in developing countries between 1991-2007, found that the implementation of the restructuring program and strict regulations since the 2001 crisis has reduced the efficiency of banks between 2004 and 2007. The results were corroborated by Akınc1 and al. (2013), who found that liberalization and restructuring programs increased as well as the performance of the banking sector. As one of the latest studies, Berument et al. (2015)-addressing foreign capital investments in different forms, including direct investments, portfolio investments and other investments for the period 2000-2012-found that foreign direct investments and portfolio investment significantly impacted the macroeconomic variables, but the effect of other investments were not statistically significant.

The studies examined above show an inconsistency regarding the relationship between FDI and economic growth on the one hand; and FDI and the banking sector performance on the other. Now, let's discover the effects of foreign portfolio investments.

\section{On Foreign Portfolio Investments'effects}

As with the case of FDI's effects, studies have also been conducted on the effects of FPIs. The results were still divergent. Edwards (2001) focusing on 65 countries between 1975 and 1997 used Panel WLS estimator, the IV-WLS, the W2SLS, W3SLS techniques and the SUR in his study. He found a positive relationship between FPI and economic growth. These results were corroborated by Agbloyor and al. (2013) analyzing 42 countries between 1970-2007 and 16 countries over 1990-2007 with panel regression. The results were particularly positive for countries in which the banking system is well advanced and where the stock market is well developed. The results were similar to those of Adeola (2017) studying 4 emerging countries over 1970-2011 using co-integration tests and the Vector Error Correction (VECM) model. However, Durham (2004) using Cross-sectional OLS regression for 80 countries over 1979-1998 found that FPIs if not controlled, lead to negative effects while Kodongo and Ojah (2012) interested in 4 countries over 1997-2009 found no significant effects.

\section{On External Debts'effects}

Studies have shown that external debts are more likely to have negative than positive effects, especially when the recipient country's environment is not favorable and/or when the debts obtained are used for illtargeted purposes (Fosu, 1996). This is especially true for short-term debts Eichengreen \& Rose (1996) and Rodrik \& Velasco (1999). these authors showed that short term debt flows become harmful to the host economy during the crisis times. In addition, evidence has shown that there are thresholds not to be crossed in terms of indebtedness. Baum and al. (2013) showed that long-term debts'effects were positive effects (if the ratio of Debt to GDP < 67\%). Effects were nil and insignificant (if the ratio of debt to GDP is between $67 \%$ and $95 \%$ ) and effects became negative over 95\%). Their study was about 12 Euro area countries over 19902010 with Panel GMM, OLS, IV 2SLS. Reinhart \& Rogoff (2010) found more interesting results by analyzing 44 countries -both advanced and emerging economies over 200 years. For the period 1946-2009, below 90\% of GDP, the relationship was weak for 20 advanced economies, while above $90 \%$ the effects became negative. In fact, a decrease of $1 \%$ is observed for the growth rate. For 24 emerging economies analyzed over 19002009 , it was found that the external debts' threshold was more stringent. Annual growth drops by $2 \%$ when the ratio of external debt to GDP achieves $60 \%$, whilst with higher debts, growth rates fall by half. According to Reisen and Soto (2001), undercapitalized banks tend to take excessive risks, which increases their exposure to government liabilities. In economies where banking systems are underfunded, there is a negative relationship between short- and long-term bank inflows and the growth rate (Soto, 2000). These results are corroborated by Aizenman et al. (2013). 


\section{On External Aids'effects}

The effects of external assistance on economic growth and financial development vary across the countries studied. Many studies have found positive order effects: Papanek in 1973, Hansen and Tarp in 2001, Karras in 2006, Asteriou in 2009, Minoiu and Reddy in 2010. But this is only possible under certain conditions. At the same time, authors such as Mosley et al. (1987), Rajan and Subramanian (2008) have also found negative effects.

\section{On Remittances'effects}

Remittances are a growing source of external funding. The entry of this private capital into the economy is done directly through individuals. Long underestimated, these international capital flows have been the focus of attention only recently (Giuliano and Ruiz-Arranz, 2009; Fayissa and Nsiah, 2010; Chowdhury, 2011). Most of studies like those of Aggarwal et al. (2011) and Gupta et al. (2009) have shown their susceptibility to improving economic growth and financial development of the host economy. Some studies, however, have nevertheless revealed negative effects (Amuedo-Dorantes \& Pozo, 2004, Rao \& Hassan, 2011)

From the previous literature review, it is clear that results from previous studies are diverging but also focused on a component of international capital flows. Our study, which takes into consideration the 5 components at the same time, is interested in the banking sector of emerging countries.

\section{Methodology and Modelization}

The study is largely quantitative and builds on existing studies and methodologies. The analytical procedures adopted in this study to estimate the effects of foreign capital flows on the banking sector is discussed in this section. It is a multiple regression model formulated as a system of equations since we have two dependent variables. Moreover, we used two different models (linear and non-linear) to check the presence of a non-linearity of this impact.

Initially, the empirical model for estimation takes a form of a system of equations (1) as follows:

$\left\{\begin{array}{l}R O E_{i t}=\lambda_{i}+\sum_{n=1}^{6} \alpha_{n} \mathrm{X}_{i t}+\sum_{n=7}^{12} \alpha_{n} \mathrm{~K}_{i t}+\lambda_{t}+\varepsilon_{i t} \\ R O A_{i t}=\lambda_{i}+\sum_{n=1}^{6} \beta_{n} \mathrm{X}_{i t}+\sum_{n=7}^{12} \beta_{n} \mathrm{~K}_{i t}+\lambda_{t}+\varepsilon_{i t}\end{array}\right.$

Where:

- The dependent variables are:

$\checkmark$ ROE $i$ : the profitability (Return on Equity) for banks type " $i$ " in year $t$.

$\checkmark$ ROAit: the profitability (Return on Asset) for banks type " $i$ " in year $t$.

- And the independent variables are:

$\checkmark \quad X_{i t:}$ the matrix of the " $n$ " international capital flows received by by Turkey in the year $t$. Namely Foreign direct investments, Foreign portfolio investments, External debts, External aids and Remittances.

$\checkmark K_{i t}$ : the matrix of the " $n$ " control variables in year $t$ (as described in table 1).

- The banks type and time fixed effects are respectively $\lambda_{i}$ and $\lambda_{t}$ while $\varepsilon_{i t}$ is the error term.

Thus, for more details, the empirical linear model can be transformed into a system of equations (1)' as follows:

$\left\{\begin{array}{l}R O E_{i t}=\alpha_{0}+\alpha_{1} \mathrm{FDI}+\alpha_{2} \mathrm{FPI}+\alpha_{3} \text { EstDebt }+\alpha_{4} \text { EltDebt }+\alpha_{5} \mathrm{EAid}+\alpha_{6} \mathrm{Rem}+\alpha_{7} \mathrm{GDP}+\alpha_{8} \mathrm{Infl}+\alpha_{9} \mathrm{Int}+\alpha_{10} \mathrm{Exchg}+\alpha_{11} \mathrm{Opns}+\alpha_{12} \mathrm{ROE}_{t-1}+\varepsilon_{1} \\ R O A_{i t}=\beta_{0}+\beta_{1} \mathrm{FDI}+\beta_{2} \mathrm{FPI}+\beta_{3} \text { EstDebt }+\beta_{4} \text { EltDebt }+\beta_{5} \mathrm{EAid}+\beta_{6} \mathrm{Rem}+\beta_{7} \mathrm{GDP}+\beta_{8} \mathrm{Infl}+\beta_{9} \mathrm{Int}+\beta_{10} \mathrm{Exchg}+\beta_{11} \mathrm{Opns}+\beta_{12} \mathrm{ROA}_{t-1}+\varepsilon_{2}\end{array}\right.$

To examine the non-linearity of international capital flows' effects on profitability, we apply a quadratic model that takes into account the explanatory variables (flow components) squared in the equation of the regression. So, the model to estimate in this context takes the form of the following systems of equations (2):

$\left\{\begin{array}{l}R O E_{i t}=\lambda_{i}+\sum_{n=1}^{6} \alpha_{n} \mathrm{X}_{i t}^{2}+\sum_{n=7}^{12} \alpha_{n} \mathrm{~K}_{i t}+\lambda_{t}+\varepsilon_{i t} \\ R O A_{i t}=\lambda_{i}+\sum_{n=1}^{6} \beta_{n} \mathrm{X}_{i t}^{2}+\sum_{n=7}^{12} \beta_{n} \mathrm{~K}_{i t}+\lambda_{t}+\varepsilon_{i t}\end{array}\right.$ 
Thus, for more details, the empirical non-linear model can be transformed into a system of equations (2)' as follows:

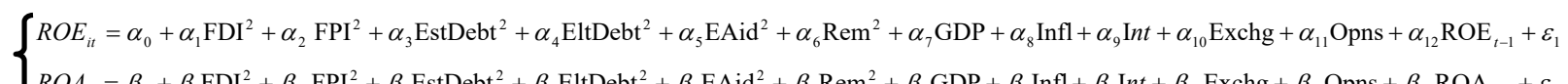

The measures (ROE and ROA) used to assess bank profitability are chosen in line with recent trends in bank performance measures (Mishkin \& Eakins, 2016). Furthermore, we use six additional control variables. These variables have proved robust in several studies dealing with the phenomenon of economic growth (see Barro and Sala-I-Martin (2003), Sala-I-Martin et al (2004). The summarised table below gives a synthetic presentation of our variables, their definitions and a priori expectation of their effects on banking sector profitability.

Table 1: The variables used, their definitions and their sources

\begin{tabular}{|c|c|c|c|c|}
\hline Variable & Symbol & Definition (Calculation) & Expected Effect & Data Sources \\
\hline \multicolumn{5}{|l|}{ 1)- Dependent variables } \\
\hline Return on Equity & ROE & Profits after tax / total Equities (\%) & NA & \multirow{2}{*}{$\begin{array}{c}\text { Databases of } \\
\text { Central Banks, } \\
\text { FRED Database }\end{array}$} \\
\hline Return on Assets & ROA & Profits after tax / Total Assets (\%) & NA & \\
\hline \multicolumn{5}{|l|}{ 2)- Independent variables } \\
\hline \multicolumn{5}{|l|}{ 2.a)-Explanatory variables } \\
\hline $\begin{array}{l}\text { International Capital Flows } \\
\text { (Aggregate to be broken down) }\end{array}$ & ICF & $\begin{array}{l}\text { Total Flows of international capital into Turkey in the year } t \text { in } \\
\text { American dollars (\% of GDP) }\end{array}$ & & \multirow{6}{*}{$\begin{array}{c}\text { Matrix } \\
\text { Database of } \\
\text { IFS, } \\
\text { IMF, } \\
\text { World Bank }\end{array}$} \\
\hline Foreign Direct Investments & FDI & Foreign Direct Investments (\% of GDP) & + & \\
\hline Foreign Portfolio Investments & FPI & Foreign Portfolio Investments ( $\%$ of GDP) & + & \\
\hline External Debts & EDBT & $\begin{array}{cc}\text { External Debt Flows (\% of GDP) } \\
-\quad \text { External Long-Term Debt Flows (ELTDBT) } \\
-\quad \text { External Short-Term Debt Flows (ESTDBT) }\end{array}$ & $\begin{array}{l}(\mathrm{LT})+ \\
(\mathrm{ST}))^{-}\end{array}$ & \\
\hline External Aids & EAID & External Aids (\% of GDP) & $+/-$ & \\
\hline Remittances & REM & Remittances (\% of GDP) & + & \\
\hline \multicolumn{5}{|l|}{ 2.b)-Controle variables } \\
\hline Home GDP growth & $\Delta \mathrm{GDP}$ & Growth in home nation GDP from year $\mathrm{t}-1$ to year $\mathrm{t}(\%)$ & + & \multirow{8}{*}{$\begin{array}{c}\text { Database of } \\
\text { IFS, } \\
\text { IMF, } \\
\text { OECD, } \\
\text { Central Banks, } \\
\text { World Bank }\end{array}$} \\
\hline Inflation rate & INFL & Annual growth rate of consumer price index; GDP deflator (\%) & $+/-$ & \\
\hline Interest rate & INT & $\begin{array}{l}\text { Nominal rate is the rate on short-term government securities or } \\
\text { the commercial bank deposit interest rate }(\%) \text {. }\end{array}$ & $+/-$ & \\
\hline Official effective exchange rate & EXCHG & Annual average dollar price & $+/-$ & \\
\hline Openness to trade & OPNS & Exports + Imports (\% of GDP) & $+/-$ & \\
\hline Return on Equity $\mathrm{t}_{\mathrm{-}-1} /$ Assets $_{\mathrm{t}-1}$ & $\mathrm{ROE} / \mathrm{A}_{\mathrm{t}-1}$ & Profits after tax delayed on one period ( $\%)$ & + & \\
\hline \multicolumn{4}{|l|}{ 3)- Dummy variables } & \\
\hline Period & Period & Period $($ Criris Period $=1 ;$ Non- crisis period $=0$ ) & & \\
\hline
\end{tabular}

Source: Created by the author based on the literature review

To estimate our dynamic models, we apply the generalized method of moments on panel (GMM) proposed by Arellano and Bond (1991), developed later by Arellano \& Bover (1995), and Blundell \& Bond (1998). According to the defenders of this method, it makes it possible to provide solutions to the problems of simultaneity bias, inverse causality, and any omitted variables. Moreover, it controls the individual and temporal-specific effects. In addition, another advantage of (GMM) method is that it also makes it possible to solve the problem of endogeneity by using a series of instrumental variables generated by the delays of the variables. In order to identify the best model specification, we performed tests. As a result, the model is estimated by the method of moments generalized in a system and in two stages.

Since the financial liberalization came into force in some emerging countries like Turkey in 1980, our study covered a 42 years period from 1975 to 2016. The period was chosen in line with the increase in international capital flows, especially to emerging countries. International capital flows are evaluated in this study with a close interest to their five components (as described above) and their effects on different types (or groups) of banks. So our sample is composed of: (1) public banks, (2) private banks, (3) foreign banks, (4) development and investment banks and (5) the whole banking sector's profitability in Turkey.

\section{Results}

We present in this section, the results of the analysis. Descriptive statistics results and correlation matrices for variables are presented in the annex (see tables 2, 3, 4 and 5). For robustness sake, we estimated the model by the GMM method in two steps and one step, and the estimates reached the same results. Regarding the effectiveness of the GMM panel estimator, previous tests have confirmed the robustness of our results. First, the Hansen test indicates that the instruments used in our regressions are valid. Because 
the validity assumption of the variables delayed in level and in difference as instruments $\left(\mathrm{H}_{0}\right)$ is accepted; with p-values well above the $10 \%$ threshold. In addition, the $\operatorname{AR}(2)$ test indicates the absence of autocorrelation between the second order error terms, with p-values greater than the $10 \%$ threshold. Results obtained are presented in tables 6 and 8 .

Table 6: Effects of International Capital Flows on Banking Sector Profitability (ROE)

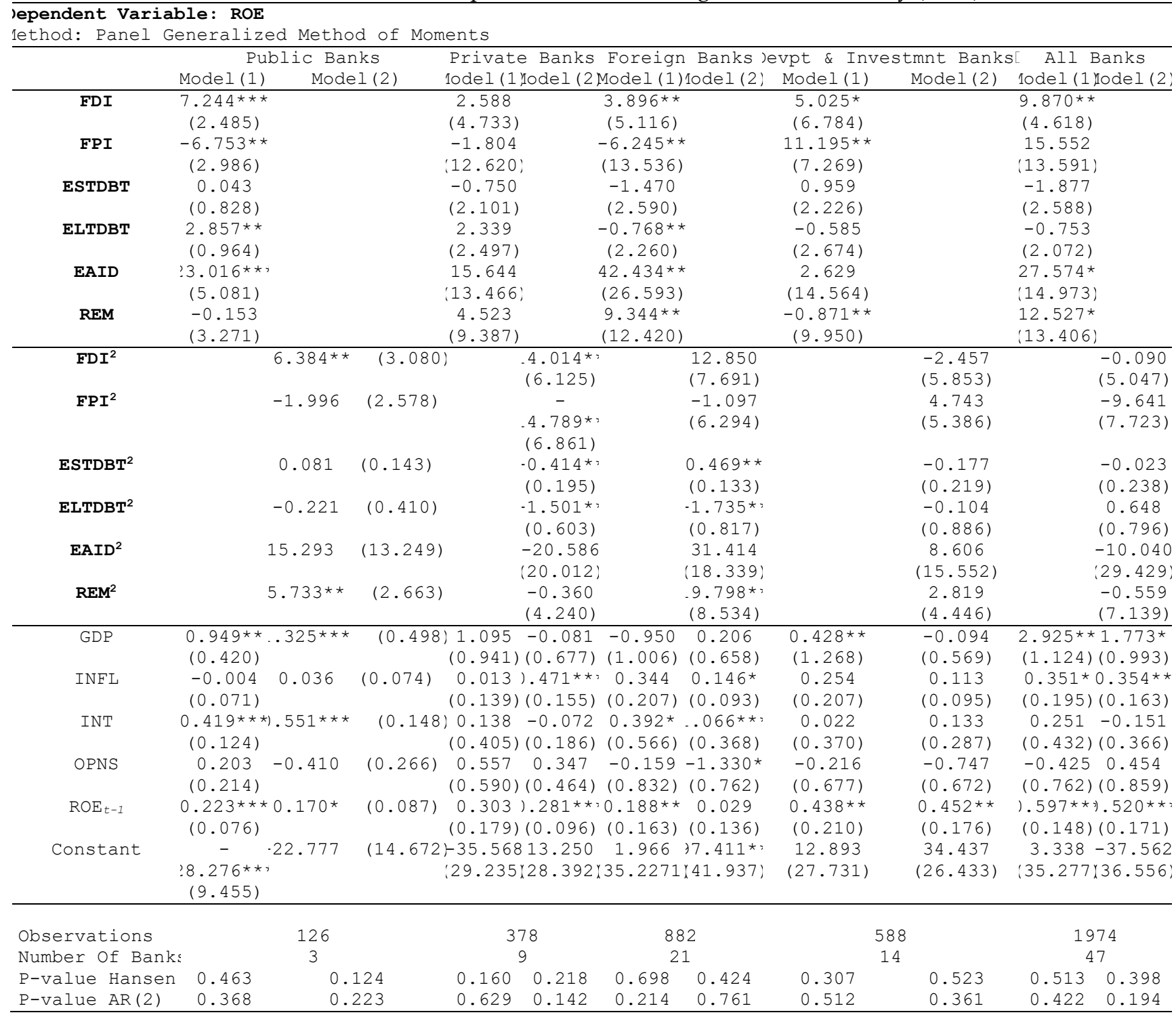

Legend: ***,** and *, indicate Statistical significance (of estimated coefficients) at the error threshold of $1 \%$, $5 \%$, and $10 \%$ level, respectively. Values in parentheses are the standard deviations of the explanatory variables' estimated coefficients, including the constant.

Source: Author's calculation with Stata software.

In order to facilitate the reading and the understanding of the results, we propose to summarize them in the synthetic table below, which seems to us much more fluid and clear. 
Table 7: Filtered and synthetic presentation of the results (Dependent variable: ROE)

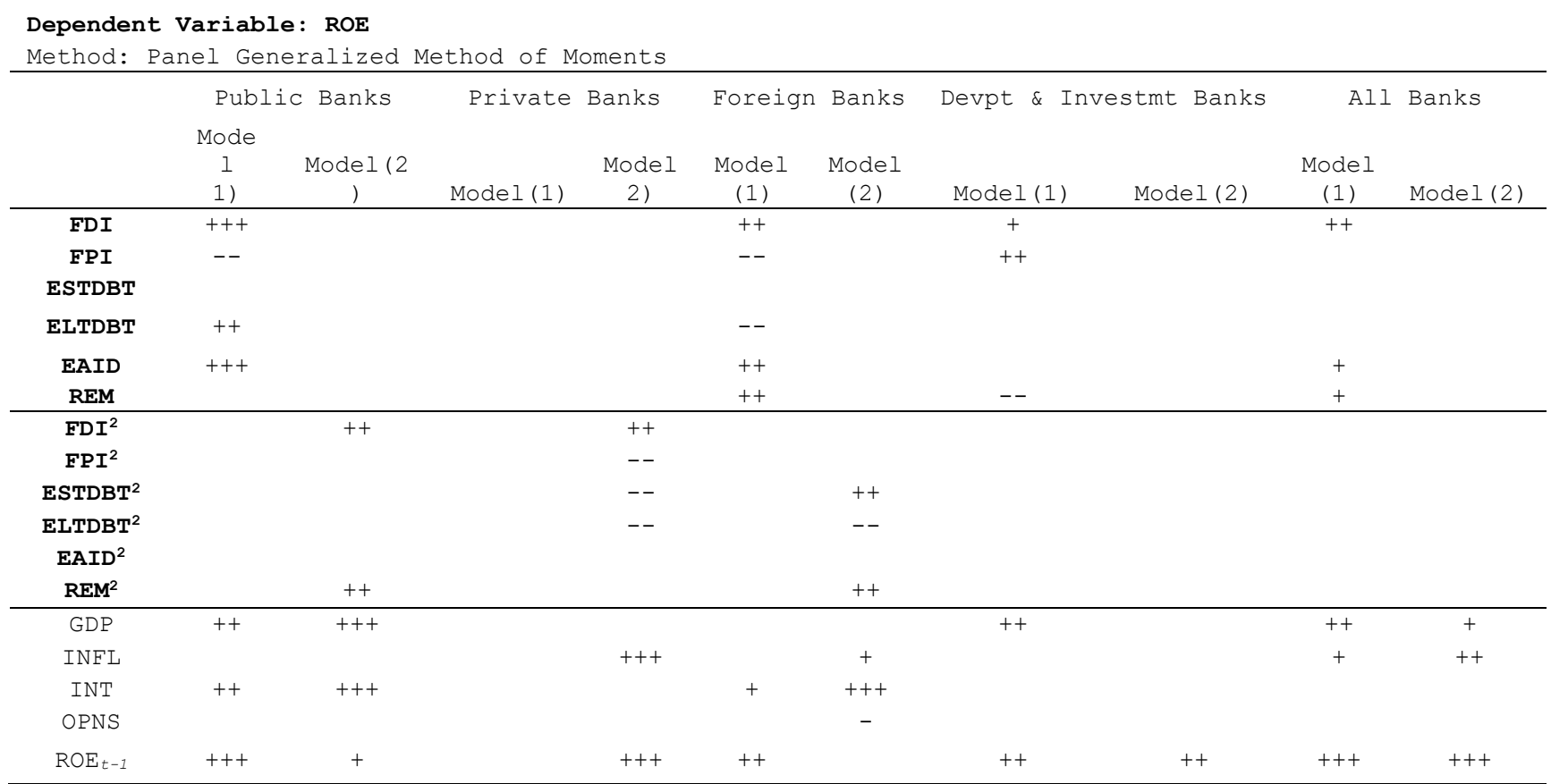

Legend: $[+++,++$ and +] or [---, -- and -], indicate "Positive effects" or "Negative effects" with statistical significance at $1 \%, 5 \%$ and $10 \%$ level, respectively.

Source: The author's own elaboration (based on estimation's results with software Stata)

Following the results from the linear model (model 1), we found that:

Foreign Direct Investments (FDI) had a positive and significant influence on banking profitability (Return on Equity: ROE) of public banks, foreign banks and the banking sector in general. These effects were less on development and investment banks. Foreign Portfolio Investments (FPI) had a negative and significant influence on ROE of public banks and foreign banks, while on development and investment banks these effects were positive. The negative effects of FPI could be in part explained by the fact that investors had chosen to invest much more in stock market and other capital markets than in banking sector for the considered period. As for the External Long Term Debt (ELTDBT), they had a positive and significant influence on the profitability (ROE) of public banks but negative on that of foreign banks. For External Aids (EAID), we noted a positive and significant effect on profitability (ROE) of public banks and foreign banks. As for Remittance (REM), we found that they positively and significantly influence the profitability (ROE) of foreign banks but negatively for that of development and investment banks. That could be explained since the majority of cross-border transfer funds were often via foreign banks which own agencies in the two countries involved in remittances.

\section{Following the nonlinear model (model 2), we noted that:}

FDI had also positive and significant effects on profitability (ROE) of public banks and private banks while FPI influenced only the profitability of private banks but in a negative way. As for the External Short Term Debts (ESTDBT), they had a negative and significant influence on the profitability of private banks but positive on that of foreign banks. While the effects of ELTDBT remained negative on the profitability of both private and foreign banks. This assumes that the acceptable threshold for debt has been crossed. On the other hand, the effects of Rem remain positive both on the profitability of public and foreign banks.

To summarize, the international capital flows which had the most positive effects on the banking sector profitability (ROE) in Turkey over the considered period are: Foreign Direct Investments (FDI), External Aids (EAID) and Remittance (REM); (confirmed by both linear and non-linear models). Those with the most negative influences are Foreign Portfolio Investments (FPI) and External long Term Debts (ELTDBT).

With regard to the control variables, we note that the most influential are the Economic growth (GDP), the Interest rate (INT) and the ROE $1-1$ as well on public banks, on foreign banks as on development and investment banks. These results are confirmed by both models (linear and nonlinear). 


\section{S. Dossou - A. Aksoy 11/4 (2019) 2456-2471}

Our results corroborated those of many other authors, even though they have been much more interested in economic growth than in banking sector profitability. We can cite: Blomstrom et al. (1996), Borensztein et al. (1998), Zhang (2001), Carkovic and Levine (2002), Hermes and Lensink (2003), Işık and Hassan (2002), Işık (2007), Denizer et al. (2007), Kılıç (2011), Aggarwal et al. (2011), Gupta et al. (2009), Reisen and Soto (2001) and Aizenman et al. (2013). At the same time, we should note that our results are contrary to those of Mosley et al. (1987), Amuedo-Dorantes \& Pozo (2004) and Rajan \& Subramanian (2008).

Now we are going to present the results about the effects of international capital flows on banking profitability (Return on Assets: ROA).

Table 8: Effects of International Capital Flows on Banking Sector Profitability (ROA)

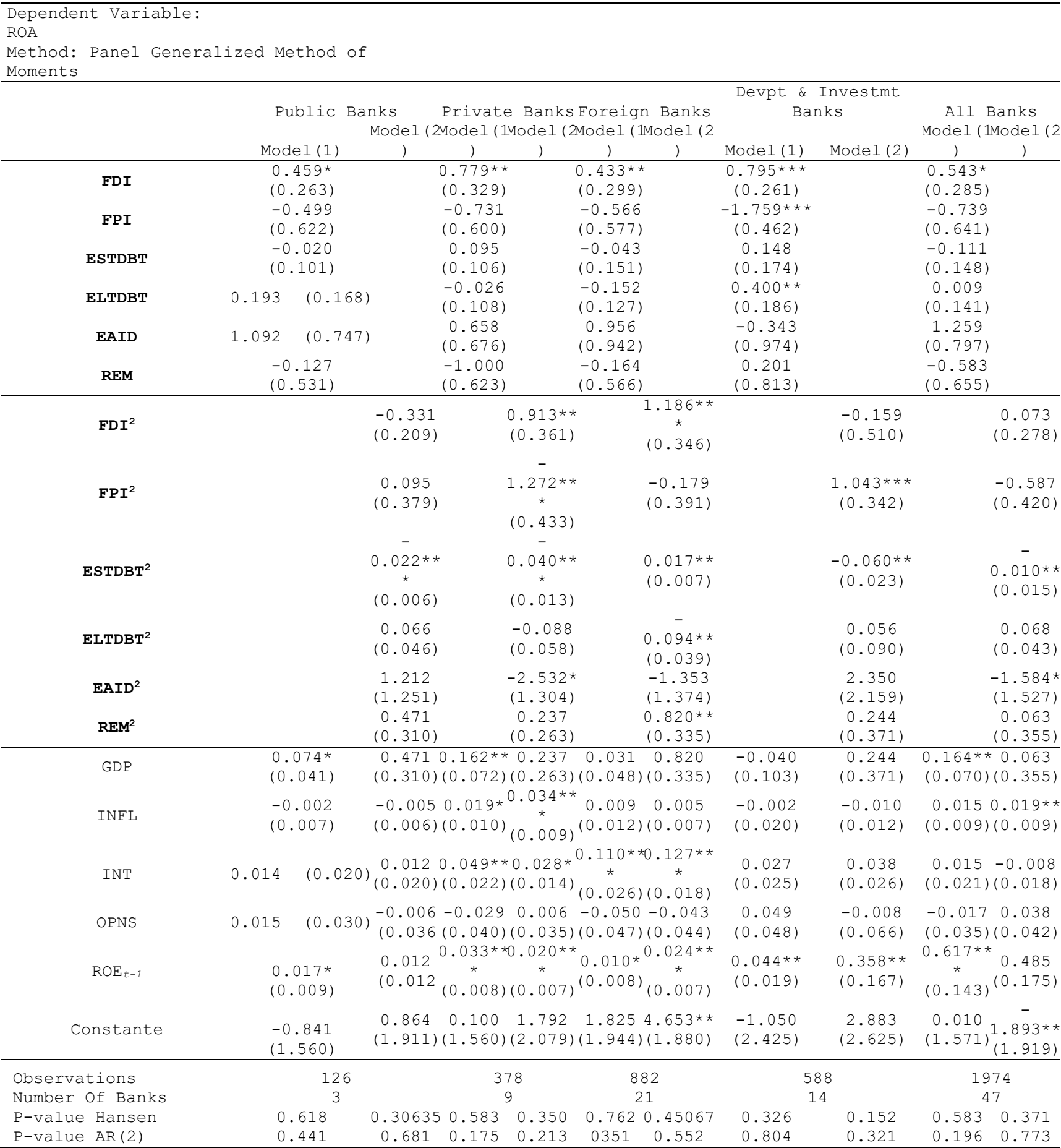

Legend: ${ }^{* * *},{ }^{* *}$ and ${ }^{*}$, indicate Statistical significance (of estimated coefficients) at the error threshold of $1 \%$, $5 \%$, and $10 \%$ level, respectively. Values in parentheses are the standard deviations of the explanatory variables' estimated coefficients, including the constant.

Source: Author's calculation with Stata software. 
The following table gives more fluidity and clear understanding of the results.

Table 9: Filtered and synthetic presentation of the results (Dependent variable: ROA)

Dependent Variable: ROA

Method: Panel Generalized Method of Moments

\begin{tabular}{|c|c|c|c|c|c|c|c|c|c|c|}
\hline & $\begin{array}{l}\text { Public } \\
\text { Model } \\
(1)\end{array}$ & $\begin{array}{c}\text { Banks } \\
\text { Model } \\
(2)\end{array}$ & $\begin{array}{l}\text { Private } \\
\text { Model } \\
(1)\end{array}$ & $\begin{array}{c}\text { Banks } \\
\text { Model } \\
(2)\end{array}$ & $\begin{array}{l}\text { Foreign } \\
\text { Model } \\
(1)\end{array}$ & $\begin{array}{c}\text { Banks } \\
\text { Model } \\
(2)\end{array}$ & $\begin{array}{l}\quad \text { Devpt } \\
\text { Investmt } \\
\text { Model } \\
(1)\end{array}$ & $\begin{array}{l}t \& \\
\text { Banks } \\
\text { Model } \\
(2)\end{array}$ & $\begin{array}{c}\text { All } \\
\text { Model } \\
(1)\end{array}$ & $\begin{array}{c}\text { Banks } \\
\text { Model } \\
(2) \\
\end{array}$ \\
\hline FDI & + & & ++ & & ++ & & +++ & & + & \\
\hline FPI & & & & & & & --- & & & \\
\hline \multicolumn{11}{|l|}{ ESTDBT } \\
\hline ELTDBT & & & & & & & ++ & & & \\
\hline \multicolumn{11}{|l|}{ EAID } \\
\hline \multicolumn{11}{|l|}{ REM } \\
\hline FDI $^{2}$ & & & & ++ & & +++ & & & & \\
\hline$F P I^{2}$ & & & & --- & & & & +++ & & \\
\hline ESTDBT $^{2}$ & & --- & & --- & & ++ & & -- & & -- \\
\hline ELTDBT $^{2}$ & & & & & & -- & & & & \\
\hline EAID $^{2}$ & & & & - & & & & & & - \\
\hline $\mathrm{REM}^{2}$ & & & & & & ++ & & & & \\
\hline GDP & + & & ++ & & & & & & ++ & \\
\hline INFL & & & + & +++ & & & & & & ++ \\
\hline INT & & & ++ & + & +++ & +++ & & & & \\
\hline OPNS & & & & & & & & & & \\
\hline $\mathrm{ROA}_{t-1}$ & + & & +++ & +++ & + & +++ & ++ & ++ & +++ & \\
\hline
\end{tabular}

Legend: $[+++,++$ and +$]$ or $[---,--$ and -], indicate "Positive effects" or "Negative effects" with statistical significance at $1 \%, 5 \%$ and $10 \%$ level, respectively.

Source: The author's own elaboration (based on estimation's results with software Stata)

\section{Following the results from the linear model (model 1), we found that:}

The FDI had a positive and significant influence on the profitability (Return on Assets: ROA) of private banks, foreign banks, and development and investment banks. These effects are less on public banks and the banking sector in general. However, FPI had a negative and significant effect only on development and investment banks' profitability (ROA), while for these same banks the effects of ELTDBT were positive. The effects of other capital flows remained insignificant according to the results of the linear model.

\section{According to the non-linear model (model 1), we noted:}

The FDI had positively and significantly influenced the profitability (ROA) of private and foreign banks while the effect of FPI is rather ambiguous: negative effect on private banks' profitability but positive on those of development and investment banks. As for ESTDBT, we found that they had a negative and significant influence on the profitability of public and private banks as well as on that of development and investment banks. However, their effects were positive on foreign banks' profitability. Also, the effects of ELTDBT remained negative on foreign banks' profitability (ROA) while those of Remittance remained rather positive on the same banks. The effects of other capital flows remained statistically insignificant according to the results from the non-linear model.

To summarize, international capital flows which had the most positive effects on banking sector profitability (Return on Assets: ROA) are only Foreign Direct Investments (FDI); (confirmed by both linear and nonlinear models). The effects of other capital flows remained statistically insignificant.

Talking about control variables, we note that the most influential are Interest (INT) and ROA $t-1$, especially on private and foreign banks' profitabilities.

\section{Conclusion}

The main objective of this paper was to analyze the effect of international capital flows (ICF) on the Turkish banking sector's profitability from 1975 to 2016. The fact that the ICFs can be growth engines and/or a source of instability (according to their volatility, the way of used or the environment); and the scarcity of studies related to their effects on the banking sector and the concentration of previous studies on economic growth motivated our study. Moreover, the disagreement between researchers is observed not only theoretically, but also empirically. 
For that, the ICFs are examined in this study with a particular interest for their five subcomponents and the effects of each of them on different types of Turkish banks. This could improve the accuracy of the estimate by reducing the heterogeneity between different types of banks. These banks are distributed as follows: public banks, private banks, foreign banks, development \& investment banks and finally all banks in general. In addition, two different models were used to analyze not only the linear effect of ICFs on profitability but also the nonlinear effect by estimating a quadratic model that takes into account the explanatory variables squared in the equation of regression. Our results were found using the Generalized Moments method (GMM) with a panel sample of Turkish banks based on 1974 observations.

Our main findings were as follows: On the one hand, Foreign Direct Investments, External Aids and Remittance had the most positive effects on banking sector profitability (Return on Equity: ROE) in Turkey; while those with the most negative influences were Foreign Portfolio Investments and External long Term Debts. On the other hand, only Foreign Direct Investments had the most positive effects on banking sector profitability (Return on Assets: ROA). The effects of other capital flows remained statistically insignificant. With regard to the control variables, we note that the most influential are the Economic growth (GDP), the Interest rate (INT).

Although this study brings some contributions, it has limitations. It would be interesting to consider some thoughts for future researches. It is necessary to extend this analysis by taking into account an enlarged sample comprising several emerging countries. In addition, the distinction of different periods "before", "between" and "post" crises would give much more accurate results.

\section{References}

Adeola, O. O. (2017, March). Foreign Capital Flows and Economic Growth in Selected Sub-Saharan African Economies, . PhD. Thesis, Stellenbosch University.

Agbloyor, E., Abor, J., Adjasi, C., \& Yawson, A. (2013). Exploring the Causality Links between Financial Markets and Foreign Direct Investment in Africa. . Research in International Business and Finance, 28, 118-134.

Aggarwal, R., Demirgüç-Kunt, A., \& Pería, M. (2011). Do Remittances Promote Financial Development? Journal of Development Economics, 96(2), 255-264.

Ağır, H. (2010). Türkiye'de Finansal Liberalizasyon ve Finansal Gelişme İlişkisinin Ekonometrik Analizi, BDDK Kitapları No:8.

Aizenman, J., Jinjarak, Y., \& Park, D. (2013). Capital Flows and Economic Growth in the Era of Financial Integration and Crisis, 1990-2010. . Open Economies Review, 24(3), 371-396.

Amuedo-Dorantes, C., \& Pozo, S. (2004). Workers' Remittances and the Real Exchange Rate: A Paradox of Gifts. . World Development, 32(8), 1407-1417.

Arellano, M. (1987). “Computing Robust Standard Errors for Within-group Estimators". . Oxford Bulletin of Economics and Statistics 49(4): 431-434.

Arellano, M., \& Bond, S. (1991). "Some Tests of Specification for Panel Data: Monte Carlo Evidence and an Application to Employment Equations",. Review of Economic Studies, 58(2), 277-297.

Arellano., M., \& Bover, O. (1995). "Another Look at the Instrumental-Variable Estimation of ErrorComponents Models",. Journal of Econometrics, 68(1), 29-52.

Asteriou, D. (2009). Foreign Aid and Economic Growth: New Evidence from a Panel Data Approach for Five South Asian Countries. . Journal of Policy Modeling, 31(1), 155-161.

Baharumshah, A., \& Thanoon, M. (2006). Foreign Capital Flows and Economic Growth in East Asian Countries. . China Economic Review, 17(1), 70-83.

Bakan, S., \& Şentürk, M. (2012). Finansal Küreselleşme Ekseninde Türkiye'ye Yönelik Sermaye Hareketleri Üzerine Bir Araştırma, . Adıyaman Üniversitesi SBE Dergisi, Yıl:5, Sayı:9, s.45-64. 
Bakan, S., \& Şentürk, M. (2012). Finansal Küreselleşme Ekseninde Türkiye'ye Yönelik Sermaye Hareketleri Üzerine Bir Araştırma, . Adıyaman Üniversitesi SBE Dergisi, Yll:5, Sayl:9, s.45-64.

Barro, R., \& Sala-I-Martin, X. (2003). Economic Growth, MIT Press, Cambridge, Massachusetts.

Baum, A., Checherita-Westphal, C., \& Rother, P. (2013). Debt and Growth: New Evidence for the Euro Area. Journal of International Money and Finance, 32, 809-821.

Berksoy, T., \& Saltoğlu, B. (1998). Türkiye Ekonomisinde Sermaye Hareketleri, İstanbul Ticaret Odası, Yayın No. 1998-58, s.13.

Berument, Hakan, Denaux, Zulal, Emirmahmutoğlu, \& Furkan. (2015). The Effects of Capital Inflows Turkish Macroeconomic Performance,. Empirica 42, 813-824.

Blomstrom, M., Lipsey, R., \& Zejan, M. (1996). Is Fixed Investment the Key to Economic Growth?,.

Blundell, R., \& Bond, S. (1998). "Initial Conditions and Moment Restrictions in Dynamic Panel Data Models",. Journal of Econometrics, 87(1), 115-143.

Borensztein, E., De Gregorio, J., \& Lee, J. (1998). How does Foreign Direct Investment Affect Economic Growth? . Journal of International Economics, 45(1), 115-135.

Chowdhury, M. (2011). Remittances Flow and Financial Development in Bangladesh. . Economic Modelling, 28(6), 2600-2608.

Claessens, S. (1995). The emergence of equity Investment in Developing Countries: Overview, The World Bank economùc Review, Vol. 9, No1, 1995, S 13.

Claessens, Stijn, Demirgüç-Kunt, Aslı, Huizinga, \& Harry. (2001). How Does Foreign Entry Affect Domestic Banking Markets?, . Journal of Banking \& Finance 25, s.891-911.

Committee, I. (2012, September). Banks and Cross-Border Capital Flows: Policy Challenges and Regulatory Responses, Committee on International Economic Policy and Reform.

Denizer, Cevdet, A., Dinç, Mustafa, Tarimcilar, \& Murat. (2007). Financial Liberalisation and banking efficiency: evidence from Turkey,. J Prod Anal 27, 177-195.

Durham, J. ( 2004). Absorptive Capacity and the Effects of Foreign Direct Investment and Equity Foreign Portfolio Investment on Economic Growth. European Economic Review, 48(2), 285-306.

Edwards, S. (2001). Capital Mobility and Economic Performance: Are Emerging Economies Different?,.

Eichengreen, B., \& Rose, A. (1998). Staying Afloat when the Wind Shifts: External Factors and EmergingMarket Banking Crises,

Fayissa, B., \& Nsiah, C. (2010). The Impact of Remittances on Economic Growth and Development in Africa. . American Economist, 55(2), 92-103.

Fosu, A. (1996). Primary Exports and Economic Growth in Developing Countries. . The World Economy, 19(4), 465-475.

Fukuyama, H., \& Matousek, R. (2011). Efficiency of Turkish Banking: Two-stage network system. Variable returns to scale model, . Journal of International Financial Markets, Institutions \& Money 21, s.75-91.

Ghosh, J. (2005). The Economic and Social Effects of Financial Liberalisation: A Primer for Developing Countries, . DESA Working Paper, No.4.

Giuliano, P., \& Ruiz-Arranz, M. (2009). Remittances, Financial Development, and Growth. . Journal of Development Economics, 90(1), 144-152.

Giuliano, P., \& Ruiz-Arranz, M. (2009). Remittances, Financial Development, and Growth. . Journal of Development Economics, 90(1), 144-152.

Gupta, S., Pattillo, C., \& Wagh, S. (2009). Effect of Remittances on Poverty and Financial Development in Sub-Saharan Africa. . World Development, 37(1), 104-115. 
S. Dossou - A. Aksoy 11/4 (2019) 2456-2471

Hansen, H., \& Tarp, F. (2001). Aid and Growth Regressions. . Journal of Development Economics, 64(2), 547-570.

Hermes, N., \& Lensink, R. (2003). Foreign Direct Investment, Financial Development and Economic Growth. . The Journal of Development Studies, 40(1), 142-163.

Hymer, S. H. (1976). The International Operations of National Firms: A Study of Direct Foreign Investment, . The MIT Press, Cambridge, Massachusetts, US and London, England.

Işık, I., \& Hassan, M. K. (2002). Technical, Scale and Allocative Efficiencies of Turkish Banking Industry, . Journal of Banking E Finance 26, 719-766.

Işık., I. (2007). Bank Ownership and Productivity Developments: Evidence from Turkey,. Studies in Economics and Finance, Vol.24, No.2, 115-139.

Kılıç, M. (2011). Cross-border Bank Acquisition and Banking Sector Performance: An Empirical Study of Turkish Banking Sector, . Procedia Social and Behavioral Sciences 24, 946-959.

Kinda., T. (2009). Determinants, Consequences And A Policy Response To Private Capital Flows In Developing Countrises. Humanities and Social Sciences. Université d'Auvergne - Clermont-Ferrand I, 2009. English. <tel-00426893>.

Masson, P. (2001). Globalisation: Facts and Figures, No:1-4, . IMF Policy Discussion Paper.

Reisen, H., \& Soto, M. (2001). Which Types of Capital Inflows Foster Developing-Country Growth? . International Finance, 4(1), 1-14.

Sala-I-Martin, X., Doppelhofer, G., \& Miller, R. (2004). “Determinants of long-term growth: a Bayesian averaging of classical estimates (BACE) approach", . American Economic Review, 94(4), 813-835.

Soto, M. (2000). Capital flows and growth in developing countries: Recent empirical evidence. OECD Development Centre. . Working paper No. 160 (Formerly technical paper No. 160) Research programme on: Capital movement and development).

World-Bank. (2013). World Bank World Development Indicators Database (WDI). Washington D.C. World Bank.

World-Bank. (2018). World Bank World Development Indicators Database (WDI). Washington D.C. World Bank.

Yalçıner, K. (2012). Uluslararası Finansman, 2. Baskı, . Detay Yayıncılık .

\section{Sites}

1. $\quad$ https://data.oecd.org/searchresults/?hf=20\&b=0\&q=Monthly

2. $\quad$ https://data.oecd.org/searchresults/?hf $=20 \& b=0 \& q=$ Quarterly

3. https://columbiaeconomics.com/2010/01/20/how-economists-convert-quarterly-data-into-monthlycubic-spline-interpolation/

4. https:/quant.stackexchange.com/questions/28230/how-to-convert-quarterly-data-to-monthly

5. https://newtonexcelbach.com/2009/07/02/cubic-splines/

6. https://stackoverflow.com/questions/34841297/vba-to-convert-quarterly-data-to-monthly

7. https://www.excelforum.com/excel-programming-vba-macros/780468-quarterly-to-monthlyconversion-macro.html

8. https://communities.sas.com/t5/General-SAS-Programming/Convert-data-from-quarterly-data-tomonthly-data-for-multiple/td-p/80677

9. $\quad$ https://support.sas.com/rnd/app/

10. http://www.princeton.edu/ otorres/InterpolationR101.pdf 


\section{Annex}

Table 2: Descriptive statistics (Dependent variable: ROE)

\begin{tabular}{ccllllrl}
\hline & Observations & Sum & Mean & Median & Maximum & \multicolumn{1}{c}{ Minimum } & Std. Dev. \\
\hline ROE & 1974 & 6278.215 & 29.89626 & 21.88984 & 181.0497 & -89.8 & 32.85889 \\
FDI & 1974 & 170.9888 & 0.814232 & 0.453879 & 3.653480 & 0.019501 & 0.885644 \\
FPI & 1974 & 150.8716 & 0.718436 & 0.478536 & 2.310107 & -0.263295 & 0.760988 \\
ESTDBT & 1974 & 130.8628 & 0.623156 & 0.859739 & 7.462914 & -6.275595 & 2.386902 \\
ELTDBT & 1974 & 445.7649 & 2.122690 & 1.988716 & 6.192091 & -1.550214 & 1.717950 \\
EAID & 1974 & 68.27028 & 0.325097 & 0.235301 & 1.385288 & 0.003561 & 0.316796 \\
REM & 1974 & 318.2781 & 1.515610 & 1.825244 & 3.505067 & 0.137314 & 1.032626 \\
GDP & 1974 & 948.2795 & 4.515617 & 5.101163 & 11.11350 & -5.962311 & 4.280838 \\
INFL & 1974 & 8792.652 & 41.86977 & 36.79066 & 143.6925 & 5.401803 & 32.57722 \\
INT & 1974 & 8052.800 & 38.34667 & 36.33917 & 87.79083 & 6.000000 & 25.31038 \\
OPNS & 1974 & 7877.961 & 37.51410 & 41.01010 & 54.97032 & 9.099744 & 12.61680 \\
ROEt-1 & 1974 & 6263.002 & 29.82382 & 21.88984 & 181.0497 & -89.8 & 32.91390 \\
\hline
\end{tabular}

Source: The author's own elaboration (Software used: Stata)

Table 3: Descriptive statistics (Dependent variable: ROA)

\begin{tabular}{ccllllrr}
\hline & Observations & Sum & Mean & Median & Maximum & Minimum & Std. Dev. \\
\hline ROA & 1974 & 511.0590 & 2.433614 & 2.116085 & 12.10236 & -4.7 & 2.107661 \\
FDI & 1974 & 170.9888 & 0.814232 & 0.453879 & 3.653480 & 0.019501 & 0.885644 \\
FPI & 1974 & 150.8716 & 0.718436 & 0.478536 & 2.310107 & -0.263295 & 0.760988 \\
ESTDBT & 1974 & 130.8628 & 0.623156 & 0.859739 & 7.462914 & -6.275595 & 2.386902 \\
ELTDBT & 1974 & 445.7649 & 2.122690 & 1.988716 & 6.192091 & -1.550214 & 1.717950 \\
EAID & 1974 & 68.27028 & 0.325097 & 0.235301 & 1.385288 & 0.003561 & 0.316796 \\
REM & 1974 & 318.2781 & 1.515610 & 1.825244 & 3.505067 & 0.137314 & 1.032626 \\
GDP & 1974 & 948.2795 & 4.515617 & 5.101163 & 11.11350 & -5.962311 & 4.280838 \\
INFL & 1974 & 8792.652 & 41.86977 & 36.79066 & 143.6925 & 5.401803 & 32.57722 \\
INT & 1974 & 8052.800 & 38.34667 & 36.33917 & 87.79083 & 6.000000 & 25.31038 \\
OPNS & 1974 & 7877.961 & 37.51410 & 41.01010 & 54.97032 & 9.099744 & 12.61680 \\
ROA -1 & 1974 & 509.2556 & 2.425027 & 2.116085 & 12.10236 & -4.7 & 2.115538 \\
\hline
\end{tabular}

Source: The author's own elaboration (Software used: Stata)

Table 4: Matrix of correlation between the variables of the regression (Dependent variable: ROE)

\begin{tabular}{|c|c|c|c|c|c|c|c|c|c|c|c|c|}
\hline & $\mathrm{ROE}$ & FDI & FPI & ESTDBT & ELTDBT & EAID & REM & GDP & INFL & INT & OPNS & $\mathrm{ROE}_{t-1}$ \\
\hline $\mathrm{ROE}$ & 1 & & & & & & & & & & & \\
\hline FDI & -0.301 & 1 & & & & & & & & & & \\
\hline $\mathrm{FPI}$ & -0.065 & 0.275 & 1 & & & & & & & & & \\
\hline ESTDBT & 0.034 & -0.126 & 0.213 & 1 & & & & & & & & \\
\hline ELTDBT & -0.134 & 0.398 & 0.412 & 0.119 & 1 & & & & & & & \\
\hline EAID & 0.207 & -0.296 & -0.339 & -0.162 & -0.096 & 1 & & & & & & \\
\hline REM & 0.425 & -0.719 & -0.392 & -0.099 & -0.385 & 0.449 & 1 & & & & & \\
\hline GDP & -0.020 & 0.052 & 0.154 & 0.562 & 0.260 & -0.111 & -0.147 & 1 & & & & \\
\hline INFL & 0.379 & -0.520 & -0.113 & -0.231 & -0.282 & 0.099 & 0.596 & -0.350 & 1 & & & \\
\hline INT & 0.313 & -0.276 & 0.147 & -0.156 & -0.301 & -0.199 & 0.366 & -0.211 & 0.695 & 1 & & \\
\hline OPNS & -0.175 & 0.622 & 0.436 & -0.052 & 0.158 & -0.478 & -0.652 & 0.149 & -0.239 & 0.247 & 1 & \\
\hline $\mathrm{ROE}_{t-1}$ & 0.690 & -0.303 & 0.059 & 0.076 & -0.137 & 0.082 & 0.401 & -0.009 & 0.329 & 0.367 & -0.114 & 1 \\
\hline
\end{tabular}

Source: Software calculation

Table 5: Matrix of correlation between the variables of the regression (Dependent variable: ROA)

\begin{tabular}{|c|c|c|c|c|c|c|c|c|c|c|c|c|}
\hline & $\mathrm{ROA}$ & FDI & FPI & ESTDBT & ELTDBT & EAID & REM & GDP & INFL & INT & OPNS & $\mathrm{ROA}_{t-1}$ \\
\hline $\mathrm{ROA}$ & 1 & & & & & & & & & & & \\
\hline FDI & -0.075 & 1 & & & & & & & & & & \\
\hline FPI & 0.095 & 0.275 & 1 & & & & & & & & & \\
\hline ESTDBT & 0.063 & -0.126 & 0.213 & 1 & & & & & & & & \\
\hline ELTDBT & -0.028 & 0.398 & 0.412 & 0.119 & 1 & & & & & & & \\
\hline EAID & -0.023 & -0.296 & -0.339 & -0.162 & -0.096 & 1 & & & & & & \\
\hline REM & 0.155 & -0.719 & -0.392 & -0.099 & -0.385 & 0.449 & 1 & & & & & \\
\hline GDP & 0.016 & 0.052 & 0.154 & 0.562 & 0.260 & -0.111 & -0.147 & 1 & & & & \\
\hline INFL & 0.264 & -0.520 & -0.113 & -0.231 & -0.282 & 0.099 & 0.596 & -0.350 & 1 & & & \\
\hline INT & 0.382 & -0.276 & 0.147 & -0.156 & -0.301 & -0.199 & 0.366 & -0.211 & 0.695 & 1 & & \\
\hline OPNS & 0.128 & 0.622 & 0.436 & -0.052 & 0.158 & -0.478 & -0.652 & 0.149 & -0.239 & 0.247 & 1 & \\
\hline $\mathrm{ROA}_{t-1}$ & 0.686 & -0.053 & 0.204 & 0.109 & -0.036 & -0.143 & 0.125 & 0.041 & 0.210 & 0.374 & 0.172 & 1 \\
\hline
\end{tabular}

Source: Software calculation 